\title{
Updated Performance Evaluation of the ISS Water Processor Multifiltration Beds
}

\author{
Elizabeth M. Bowman, Ph.D. ${ }^{1}$ \\ The Boeing Company, Huntsville, AL, 35824 \\ Layne Carter ${ }^{2}$ \\ NASA Marshall Space Flight Center, Huntsville, AL, 35812 \\ Joyce Carpenter ${ }^{3}$ \\ HSSSI, Windsor Locks, CT, 06096 \\ Nicole Orozco ${ }^{4}$ \\ The Boeing Company, Houston, TX, 77058 \\ Natalee Weir ${ }^{5}$ \\ The Boeing Company, Huntsville, AL, 35824 \\ and \\ Mark Wilson ${ }^{6}$ \\ The Boeing Company, Houston, TX, 77058
}

\begin{abstract}
The ISS Water Processor Assembly (WPA) produces potable water from a waste stream containing humidity condensate and urine distillate. The primary treatment process is achieved in the Multifiltration Beds, which include adsorbent media and ion exchange resin for the removal of dissolved organic and inorganic contaminants. Two Multifiltration Beds (MF Beds) were replaced on ISS in July 2010 after initial indication of inorganic breakthrough of the first bed and an increasing Total Organic Carbon (TOC) trend in the product water. The first bed was sampled and analyzed Sept 2011 through March 2012. The second MF Bed was sampled and analyzed June 2012 through August 2012. The water resident in the both beds was analyzed for various parameters to evaluate adsorbent loading, performance of the ion exchange resin, microbial activity, and generation of leachates from the ion exchange resin. Portions of the adsorbent media and ion exchange resin were sampled and subsequently desorbed to identify the primary contaminants removed at various points in the bed in addition to microbial analysis. Analysis of the second bed will be compared to results from the first bed to provide a comprehensive overview of how the Multifiltration Beds function on orbit. New data from the second bed supplements the analysis of the first bed (previously reported) and gives a more complete picture of breakthrough compounds, resin breakdown products, microbial activity, and
\end{abstract}

\footnotetext{
${ }^{1}$ Lead Chemist \& Technical Lead Engineer, Boeing Huntsville Laboratories, Boeing Research \& Technology, JW56, Huntsville, AL 35824, Senior Member.

${ }^{2}$ Life Support Development Team Lead, NASA, MSFC ES62, Huntsville, AL 35812, Senior Member.

${ }^{3}$ Staff Engineer, Hamilton Sundstrand Space Systems International (HSSSI), A UTC Aerospace Systems Company, One Hamilton Road, M/S 1A-2-W66, Windsor Lockst CT 06096.

${ }^{4}$ Water Processor Assembly / Water Recovery \& Management Subsystem Lead, Environmental Control and Life Support, 3700 Bay Area Blvd., Houston, TX 77059.

${ }^{5}$ Lead Microbiologist, Boeing Huntsville Laboratories, JW-56, Huntsville, AL 35824.

${ }^{6}$ Associate Technical Fellow, Boeing Research \& Technology, 13100 Space Center Blvd., MC HB3-20, Houston, TX 77059, Senior Member.
} 
difficult to remove compounds. The results of these investigations and implications to the operation of the WPA on ISS are documented in this paper.

\section{Nomenclature}

$\begin{array}{ll}\mu \mathrm{g} & =\text { microgram } \\ \mathrm{BHL} & =\text { Boeing Huntsville Laboratories } \\ \text { CFU } & =\text { colony forming units } \\ \text { DMSD } & =\text { dimethylsilanediol } \\ \text { EPA } & =\text { Environmental Protection Agency } \\ \text { g } & \text { gram } \\ \text { GC-FAME } & \text { gas chromatograph }- \text { fatty acid methyl ester } \\ \text { GC-MS } & =\text { gas chromatography }- \text { mass spectrometry } \\ \text { ISS } & =\text { Internation Space Station } \\ \text { L } & =\text { liter } \\ \text { MF Bed } & \text { Multifiltration Bed } \\ \text { mg } & =\text { milligram } \\ \text { mL } & =\text { milliliter } \\ \text { ppm } & =\text { parts per million } \\ \text { ppb } & \text { parts per billion } \\ \text { S/N } & =\text { serial number } \\ \text { SEM } & =\text { scanning electron microscope } \\ \text { TIC } & =\text { Total Inorganic Carbon } \\ \text { TNTC } & =\text { too numerous to count } \\ \text { TOC } & =\text { Total Organic Carbon } \\ \text { TOCA } & =\text { Total Organic Carbon Analyzer } \\ \text { UPA } & =\text { Urine Processor Assembly } \\ \text { HSSSI } & =\text { Hamilton Sundstrand Space Systems International, A UTC Aerospace Systems Company } \\ \text { VFA } & =\text { volatile fatty acids } \\ \text { WPA } & =\text { Water Processor Assembly }\end{array}$

\section{Introduction}

$\mathrm{T}$ he International Space Station (ISS) Water Processor Assembly (WPA) was initially activated in November of 2008 and is used to produce potable water from humidity condensate, Urine Processor Assembly (UPA) distillate, and Sabatier product water. The ISS WPA has been described and reported on elsewhere (1). This paper will focus on a key technology of the WPA, which is the use of Multifiltration (MF) Beds that contain adsorbent media and ion exchange resins to remove dissolved organic and inorganic contaminants. Two MF Beds in the WPA are used in series, with a conductivity sensor between them to monitor for the breakthrough of ionic contaminants through the first bed. Effluent from the MF Beds is further processed through a Catalytic Reactor to oxidize low molecular weight organics that are not efficiently removed by the MF Bed adsorbents. A Total Organic Carbon Analyzer (TOCA) on the ISS provides weekly analysis of the WPA product water quality.

Between June and November of 2010, on orbit TOCA measurements showed steadily increasing concentrations of Total Organic Carbon (TOC) in the WPA product water. Analysis of the product water identified dimethylsilanediol (DMSD) as the primary contributor to the rise in TOC (1). Prior to identifying DMSD, the decision was made to replace both MF Beds to address the concern that a larger organic contaminant was passing through the MF Bed and possibly impacting reactor performance. This maintenance activity occurred on July 29 2010. At the time the beds were replaced, on-orbit conductivity data indicated that initial ionic breakthrough of the first MF Bed had occurred. Both MF Beds were then stored on orbit for several months, returned to ground, and stored again for several months, with intermittent refrigeration. In August and September of 2011, MF Bed S/N 0003, which was the first bed in line in the WPA on orbit, was shipped and sampled at the HSSSI Windsor Locks facility. Samples included water and sorbent samples from each of the ten tubes that comprise the single MF Bed. Samples were sent to various laboratories for analysis, including HSSSI (where sampling occurred) and Boeing Huntsville Laboratories (BHL). Analysis results and some of their implications with respect to MF Bed life and capacity were discussed previously (2). In addition to the removal of expected contaminants, some unexpected contaminants, notably dimethylsilanediol (DMSD) and other silicon containing compounds, were also observed both 
in the water and sorbent samples from MF Bed S/N 0003 (2). Because the presence of siloxanes and DMSD in the wastewater feed to the WPA was unexpected, these compounds were not included in the design and testing of the MF Beds. Almost one year later in June and July of 2012, MF Bed S/N 0004, which was the second bed in line in the WPA, was sampled at HSSSI. Water samples were analyzed at the HSSSI chemistry lab and sent to Boeing Huntsville Laboratories for further analysis. Selected sorbent samples were also sent to BHL for analysis. Results of analyses of MF Bed S/N 0004 samples are presented here with a comparison to results from MF Bed S/N 0003 and the implications of those results for life and capacity.

\section{Sampling and Analysis Approach for Multifiltration Bed S/N 0004}

MF Bed S/N 0004 was received at HSSSI facilities in March, 2012 and was sampled in June, 2012. The MF Bed consists of ten tubes (Figure 1) containing various sorbent media, with the first three tubes containing adsorbent and the last seven tubes containing ion exchange resin. Once the tubes were opened, samples of MF Bed S/N 0004 water were taken by draining water from each tube using minimal pressure from 0.2 micron filtered notrogen to recover approximately $1 \mathrm{~L}$ of water from each tube into a sterile flask. The water was briefly stirred and then samples were collected, first for microbiological and then for chemical analysis. Samples for microbial analysis were collected into a sterile $15 \mathrm{~mL}$ centrifuge tubes, and chemical samples were collected into clean glass jars and centrifuge tubes. After draining the water, each tube from the MF Bed was then opened, a measurement of bed depth taken where possible, and the sorbent pushed out into a disinfected catch tray and sampled as follows. The first sample was a composite sample containing a few grams of sorbent from the inlet, middle and outlet that was placed in a sterile $15 \mathrm{~mL}$ centrifuge tube containing neutralizing buffer and thoroughly vortexed for microbiological analysis. Separate samples were then collected from the inlet, middle, and outlet portion of the sorbents for chemical analysis and archival storage. Next, the sorbent was stirred manually with a sterile scoop, and composite samples were collected. The two resins in tube 9 were sampled separately, which was easily accomplished due to their physical separation by a screen. Swab samples for SEM analysis were taken as needed during sampling, typically where any residue was observed. This paper will discuss physical data and analysis results in terms of tube number (1-10) for water and sorbent media samples, noting inlet, middle, outlet, and composite sorbent samples where appropriate. Comparisons between MF Bed S/N 0003 (installed first in line in the WPA) and MF Bed S/N 0004 (installed second in line) will be made, referring to samples in terms of bed and tube number (e.g. 4.6 refers to MF Bed S/N 0004, tube 6).

\section{MF Bed Schematic}

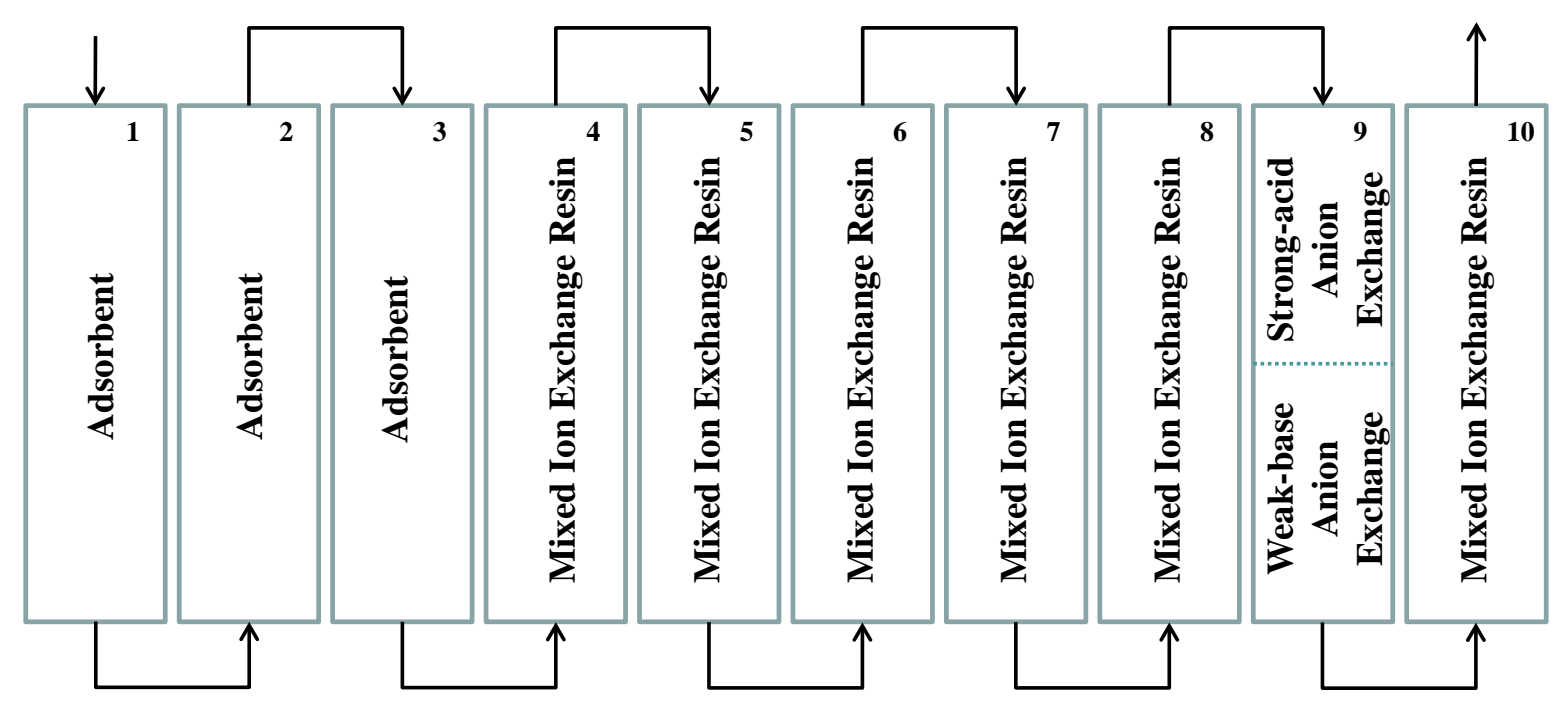

Figure 1. MF Bed schematic showing tube numbers, flow paths, and resin types. 
In contrast to the very complete analysis of samples taken from MF Bed S/N 0003 that was described previously (2), a limited set of analyses for MF Bed S/N 0004 was selected based on results from MF Bed S/N 0003. Water samples from each tube were analyzed by HSSSI for water pH, TOC/TIC, and conductivity. Further analysis of the water samples by BHL were limited to semivolatile organic compounds (based on EPA 625 methods) and volatile fatty acids (VFAs) by a direct inject GC-MS method developed at BHL. Chemical analysis of the sorbent media samples was limited to semivolatile compounds on the adsorbents in tubes 1-3, selective semivolatile compounds (base desorb followed by base / neutral extraction) of selected resin samples (tube 4 inlet and tube 10 inlet, middle, and outlet), and volatile fatty acids on the same resin samples from tubes 4 and 10 . The adsorbents were desorbed sequentially with methanol, 30\% (by volume) methanol in dichloromethane, and two aliquots of dichloromethane. Each desorption occurred overnight. The combined desorbate was then analyzed for semivolatile organic compounds by GC-MS. The selected ion exchange resin samples were desorbed with base, and the desorbate was extracted into dichloromethane to isolate basic and neutral compounds. The extract was concentrated and analyzed via GC-MS. This desorption and extraction combination was selected to capture analytes of interest based on results from analysis of the ion exchange resins from the first MF Bed. These analytes included amines that were previously identified as weak base anion exchange resin breakdown products (or leachates) and silane and siloxane compounds, which are primarily neutral and were suspected of being poorly retained by the MF Bed.

For microbiological analysis, bacteria and fungi were released from the sorbent media and swab samples into the neutralizing buffer by the standard technique of vortexing for 30 seconds, then sonicating for 1 minute, repeated three times. The heterotrophic membrane filtration method of enumeration was performed per Standard Methods for the Examination of Water and Wastewater, $17^{\text {th }}$ ed., 1989. Membrane filtration was performed in replicate on the samples and dilutions of the samples and the membrane filters placed onto R2A medium (total heterotrophic bacteria) and mEmmon's plates (total fungi). The R2A plates were incubated for 7 days at $28^{\circ} \mathrm{C}\left(82^{\circ} \mathrm{F}\right)$, and any colonies counted after completion of incubation period. The mEmmon's plates were incubated for 5 days at $25^{\circ} \mathrm{C}$ $\left(77^{\circ} \mathrm{F}\right)$, and any colonies counted after completion of the incubation period. For plates with countable colonies (positive results), each colony morphology was isolated. If a sample contained a colony morphology on a too numerous to count (TNTC) plate, but that morphology was diluted out of the countable plate, these colonies were isolated also. Identifications were performed using fatty acid methyl ester analysis by gas chromatography (GCFAME) with MIDI Sherlock ${ }^{\circledR}$ Microbial identification software version 6.1 and Biolog ${ }^{\circledR}$ Bacterial analysis using substrate utilization patterns. Organisms that could not be identified were compared with previously unidentified organisms using MIDI dendrogram comparison analysis.

During sampling, the change in sorbent bed length in each tube was measured when possible. For many resins, shrinkage in resin volume (measured as a decrease in bed length within the tube) is related to the amount of material sorbed onto the resin, so this measurement provides insight into resin usage for those tubes for which the resin was not analyzed.

\section{Measurement and Analysis Results}

\section{A. Physical and Wet Chemistry Measurements}

The change in sorbent bed length for each tube is shown in Table 1 . The first three adsorbents experience little change in sorbent bed length, which is expected given that this absorbent has little elasticity to expand or contract. Tubes 4 through 6 , however, show a decrease in length due to contraction or shrinkage of the mixed cation/anion exchange resin on use. Tubes 4 and 5 , being the first ion exchange resin tubes, absorbed the most ions, and therefore show the greatest decrease in sorbent bed length. Tubes 7 and 8 show very little change in length and are comparable to the adsorbent in tube 1 because few ions pass through the earlier tubes and remain to be absorbed in these tubes. The decrease in sorbent bed length is indicative of sorbent use for the ion exchange resin in tubes 4 through 8 ; the

Table 1. Change in sorbent bed length in $\mathrm{cm}$ (inches) for each tube in MF Bed S/N 0004.

\begin{tabular}{|c|c|}
\hline Tube number & $\begin{array}{c}\text { Change in sorbent bed } \\
\text { length, cm (inches) }\end{array}$ \\
\hline 1 & $-0.343(-0.135)$ \\
\hline 2 & $-0.005(-0.002)$ \\
\hline 3 & $-0.234(-0.092)$ \\
\hline 4 & $-3.86(-1.519)$ \\
\hline 5 & $-4.00(-1.576)$ \\
\hline 6 & $-2.19(-0.863)$ \\
\hline 7 & $-0.262(-0.103)$ \\
\hline 8 & $-0.330(-0.130)$ \\
\hline 9 & $-1.17(-0.462)$ \\
\hline 10 & not available \\
\hline
\end{tabular}

American Institute of Aeronautics and Astronautics 
greater the decrease, the greater the sorption of ions on the resin. For Tube 9, the measured contraction is inconclusive by itself because tube 9 has two different resins in it, one of which expands during use and the other which contracts during use. The measured decrease is a combination of both expansion and contraction for the two different resins. Tube 10 sorbent bed length change was not measureable due to hardware constraints.

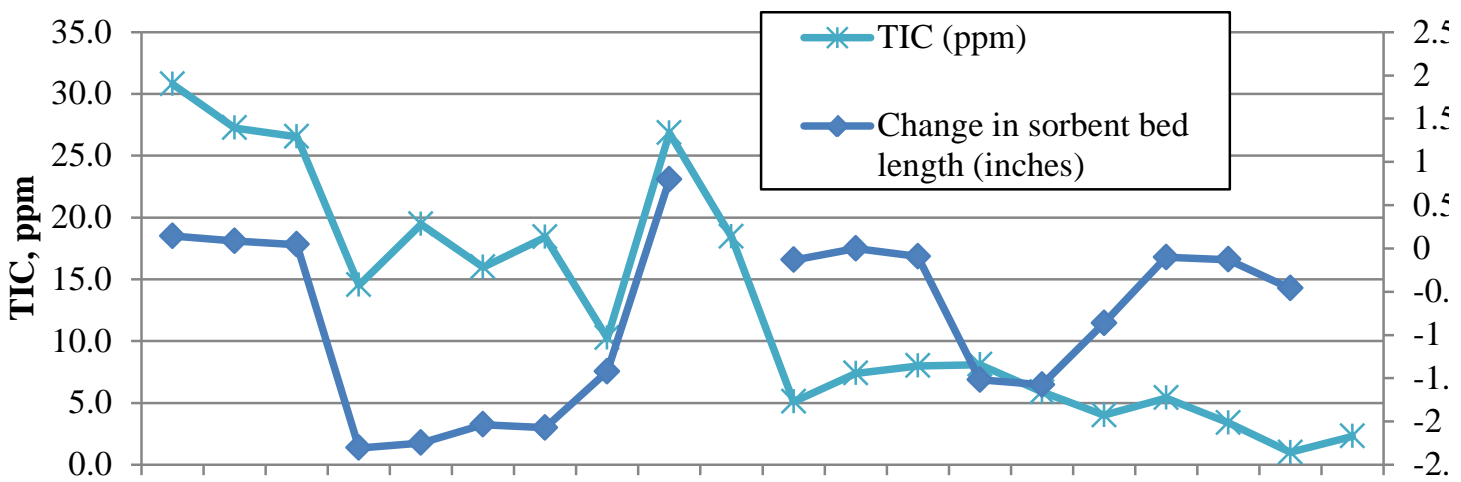

$\begin{array}{llllllllllllllllllll}3.1 & 3.2 & 3.3 & 3.4 & 3.5 & 3.6 & 3.7 & 3.8 & 3.9 & 3.10 & 4.1 & 4.2 & 4.3 & 4.4 & 4.5 & 4.6 & 4.7 & 4.8 & 4.9 & 4.10\end{array}$

Bed and Tube Number

Figure 2. Total inorganic carbon (TIC) and change in sorbent bed length for MF Beds S/N 0003 and 0004 , installed as the first and second beds, respectively.

Figure 2 shows the profile of TIC and the change in sorbent bed length for both MF Beds. TIC (primarily bicarbonate ion) is expected to be the first breakthrough ion of an MF Bed as designed, and it is expected to be followed by acetate ion. Analysis of MF Bed S/N 0003 showed that bicarbonate ion had broken through (2), and so bicarbonate ion is expected to be present in MF Bed S/N 0004. One goal of this analysis was to determine the extent to which bicarbonate ion had traveled through this second-in-line bed. The TIC in S/N 0004 is indeed lower than what was observed in S/N 0003 as can be seen by the general decrease from left to right across the graph, and TIC continues to decrease through MF Bed S/N 0004. It is likely that TIC in the bicarbonate ion form is the primary ion adsorbed onto the ion exchange resins in MF Bed S/N 0004, causing the decrease in bed length in tubes 4 through 6. The very low levels of TIC in tubes 4.8, 4.9, and 4.10, coupled with the small changes in sorbent bed length, indicate that bicarbonate ion had not yet broken through MF Bed S/N 0004. During sampling, swab samples of residues in tubes 3, 5, and 7 were collected for SEM analysis. The SEM swab sample analysis showed primarily iron, oxygen, and varying amounts of nickel and chromium. Although the SEM results also indicate the presence of inorganic salts that could also be sorbed by the ion exchange resins in those tubes, the amount of these salts is likely

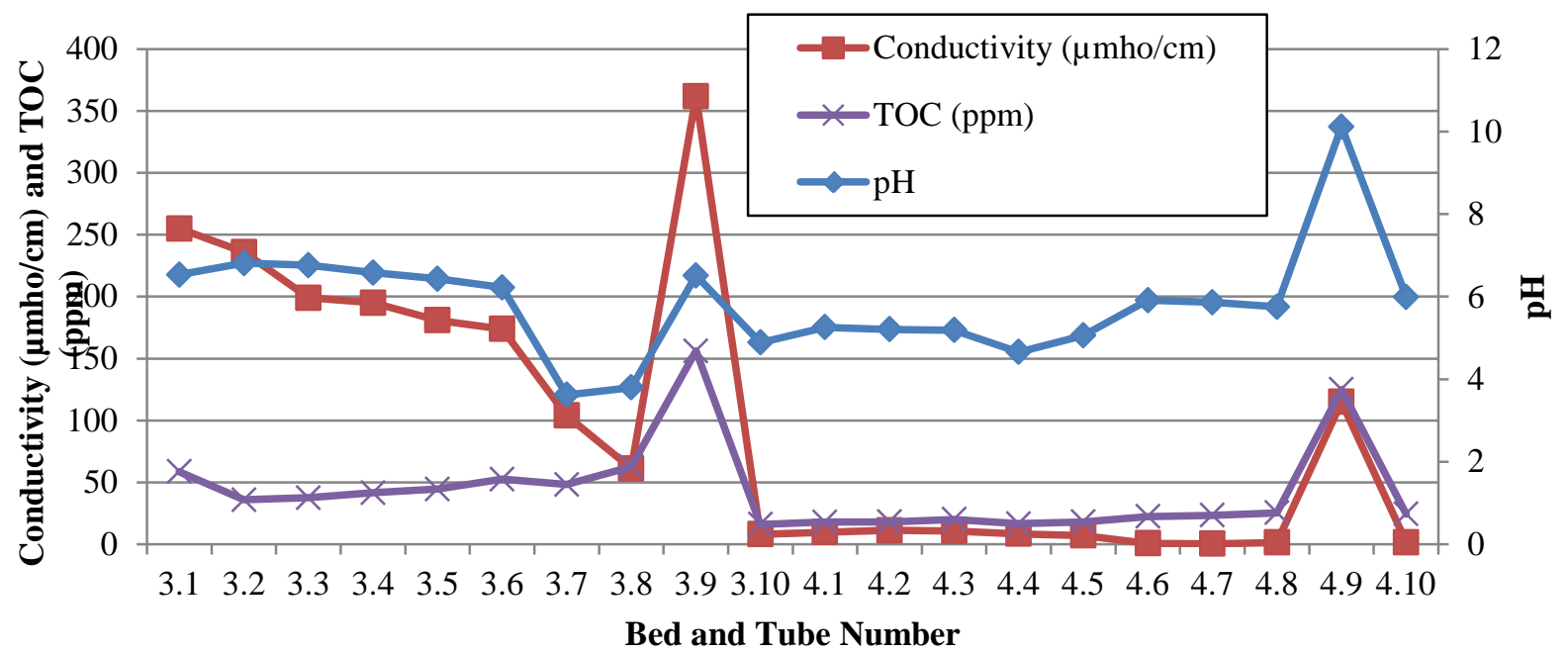

Figure 3. MF Bed S/N 0003 and 0004 conductivity, TOC, and pH measurements in water. $\mathrm{X}$-axis is labeled as SN.tube number (i.e. 4.6 indicates MF Bed S/N 0004, tube 6). 
to be low, based on similar residues seen in MF Bed S/N 0003. Swab samples from tube 10 showed the additional presence of titanium and bismuth. Swab samples from a white residue on the interior surfaces of tubes 6, 9, and 10 also showed the presence of fluorine, which could easily be related to the material lining the tube.

Figure 3 shows a graph of the measured conductivity, total organic carbon (TOC) and $\mathrm{pH}$ for both MF Beds. The conductivity clearly decreases through S/N 0003 (left side of graph, 3.1-3.10), with the exception of tube 3.9. In tube 9 of MF Bed S/N 0003, both acetic acid and a breakdown product of the weak base ion exchange resin (previously identified as $\mathrm{N}, \mathrm{N}$-dimethyl-1,3-propanediamine) are present in the water (2). In comparison, the conductivity in S/N 0004 (right side of graph, 4.1-4.10) is quite low, again with the exception of tube 9, where again the resin breakdown product $\mathrm{N}, \mathrm{N}$-dimethyl-1,3-propanediamine is likely to be present in the water. As will be discussed in the organics analysis section below, tube 4.9 water did not contain measurable acetate ion, so its conductivity is less than that of tube 3.9 water. The $\mathrm{pH}$ in water from S/N 0003 was discussed previously (2), where the decrease in tubes 3.7 and 3.8 was attributed to the presence of volatile fatty acids. The $\mathrm{pH}$ in $\mathrm{S} / \mathrm{N} 0004$ is relatively constant except for tube 4.9 , where the $\mathrm{pH}$ increases to over 10 . The high $\mathrm{pH}$ and conductivity measured in the water from tube 9 both indicate the presence of $\mathrm{N}, \mathrm{N}$-dimethyl-1,3-propanediamine $(\mathrm{pKa}=8.8$ and 10.8 (3)) which would produce a high $\mathrm{pH}$ without the neutralizing presence of acetic acid. The flat TOC profile through S/N 0004 with a peak in tube 9 also indicates the absence of many other compounds, such as acetic acid.

\section{B. Analysis of Organics in Water}

Semivolatile organic compounds were measured in the water samples from MF Bed S/N 0004. Figure 4 and

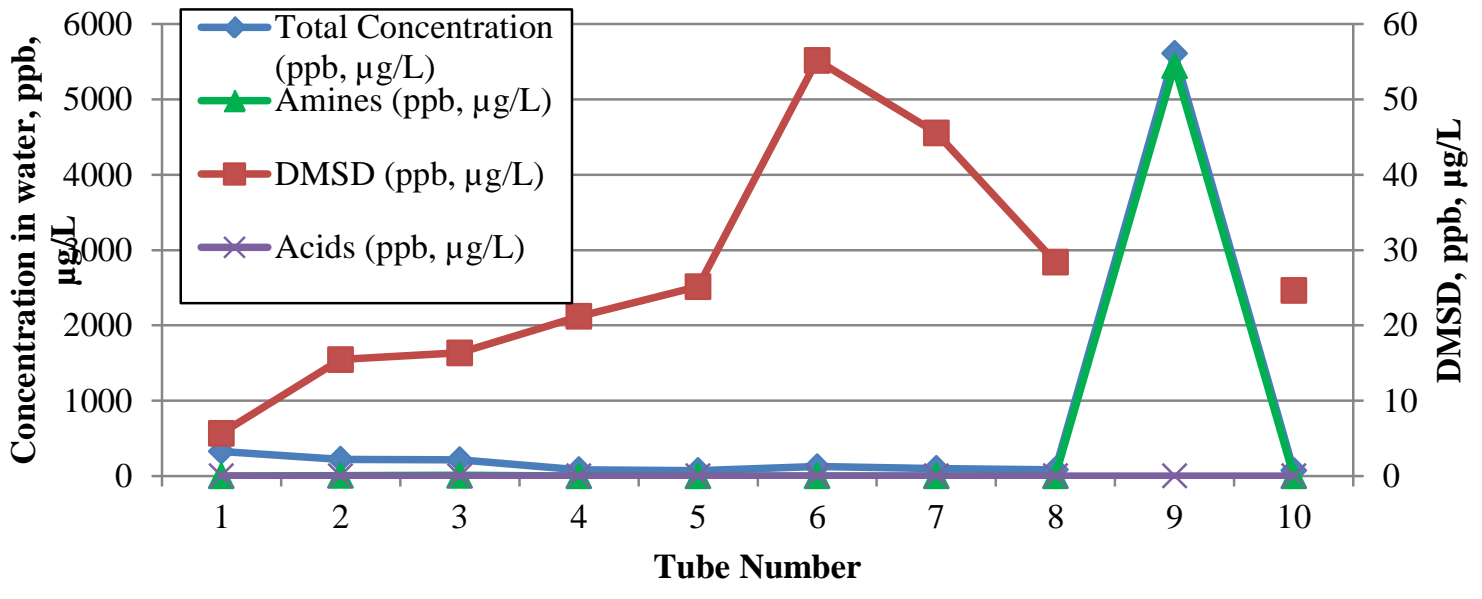

Figure 5. Water semivolatiles summary, MF Bed S/N 0004. The only silane / siloxane compound observed in the water samples was DMSD. Note that this method is biased quite low for DMSD but is still useful for trending. Note v-axis srales.

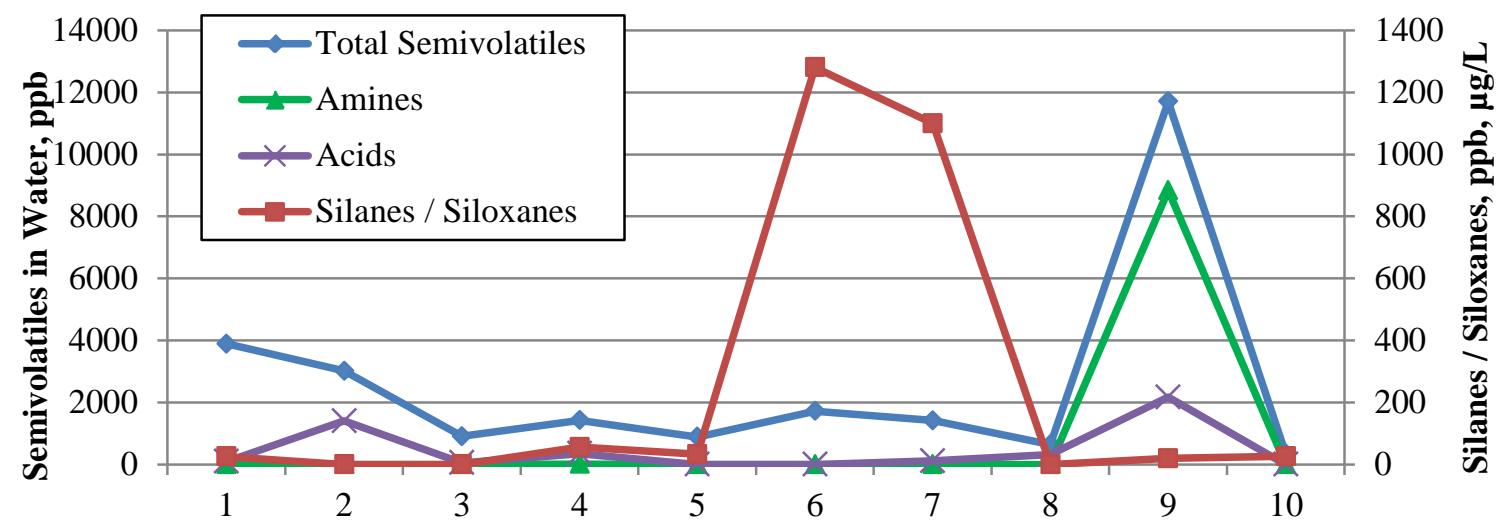

Tube Number

Figure 4. Water semivolatiles summary, MF Bed S/N 0003 for comparison purposes. Note y-axis scales.

u

American Institute of Aeronautics and Astronautics 
Figure 5 show summaries of those results for MF Bed S/N 0004 and 0003, respectively, where the compounds have been classified as amines, acids, or silanes / siloxanes. Amines, primarily N,N-dimethyl-1,3-propanediamine, were observed in tube 4.9 water at a concentration of about $5500 \mathrm{ppb}$ or $\mu \mathrm{g} / \mathrm{L}$ (as compared to over $8000 \mathrm{ppb}$ in tube 3.9). No semivolatile acidic compounds were observed in the MF Bed S/N 0004 water samples. Even though the semivolatiles method is biased low for volatile fatty acids (VFAs), this indicates that acetate ion was not breaking through the first bed. A specific analysis for volatile fatty acids was done to confirm that there was little or no acetate breaking through the first MF Bed S/N 0003. All VFAs in the water samples from MF Bed S/N 0004 were below the detection limit of about $5 \mathrm{ppm}$. Based on the amine and acid content, it is clear that the weak base ion exchange resin breakdown still occurred in MF Bed S/N 0004 in the absence of acetic acid. Additionally, the very low level of N,N-dimethylpropanediamine in the water from tube 4.10 indicates that any of this breakdown product that was produced during use was likely absorbed by the resin in tube 4.10. This is further discussed in the section on resin analysis below. As noted above, silicon containing compounds were of interest based on results from analysis of the first MF Bed, where their presence mid-bed was unexpectedly observed. The only silicon containing compound positively identified in the MF Bed S/N 0004 water samples was DMSD. In comparison, the water from MF Bed S/N 0003 contained a variety of silanes and siloxanes. Unfortunately, the method used for MF Bed S/N 0003 did not capture DMSD, so a direct comparison of DMSD in the two beds is impossible. The method used for $\mathrm{S} / \mathrm{N} 0004$ is biased quite low for DMSD, but the data is still useful for showing trends. It is likely that the true concentrations of DMSD in water samples and loadings on ion exchange resins are as much as ten times greater than the values measured and reported here. Even with the lack of DMSD detection in MF Bed S/N 0003, it is notable that the peak of silanes / siloxanes concentration occurred in tubes 6 and 7 in both MF Beds S/N 0004 and S/N 0003. The authors hypothesize that these compounds are chromatographed through the beds and are being pushed downstream by more strongly adsorbed species such as bicarbonate ion. These results, in part, led to further work to investigate the competitive sorption of bicarbonate and DMSD on ion exchange media.

Figure 6 shows the concentration (ppb in water) profiles for some selected semivolatile compounds in MF Beds S/N 0003 and 0004. Missing points indicate that a particular compound was not identified in that sample, which may be due to very low concentration or due to the peak being obscured by a compound at much higher concentration. Dimethyl sulfone (red line) is distributed throughout the water samples of both beds, indicating that the sorbents are saturated with respect to dimethyl sulfone. N,N-dimethylformamide (gold line) is adsorbed in MF Bed S/N 0003 but appears again in S/N 0004 water samples. It is possible that $\mathrm{N}, \mathrm{N}$-dimethylformamide is retained in both beds (breaking through $\mathrm{S} / \mathrm{N}$ 0003) and then desorbed off of the resin in tube 3.9 and the adsorbent in tubes 4.1 through 4.3 during storage. It is also possible, based on the small amount of N,N-dimethylformamide observed in tube 4.9, that this compound is present in small amount as a breakdown product of the weak base anion exchange resin in tube 9 (in addition to the much larger amount of dimethylformamide known to be present in the WPA

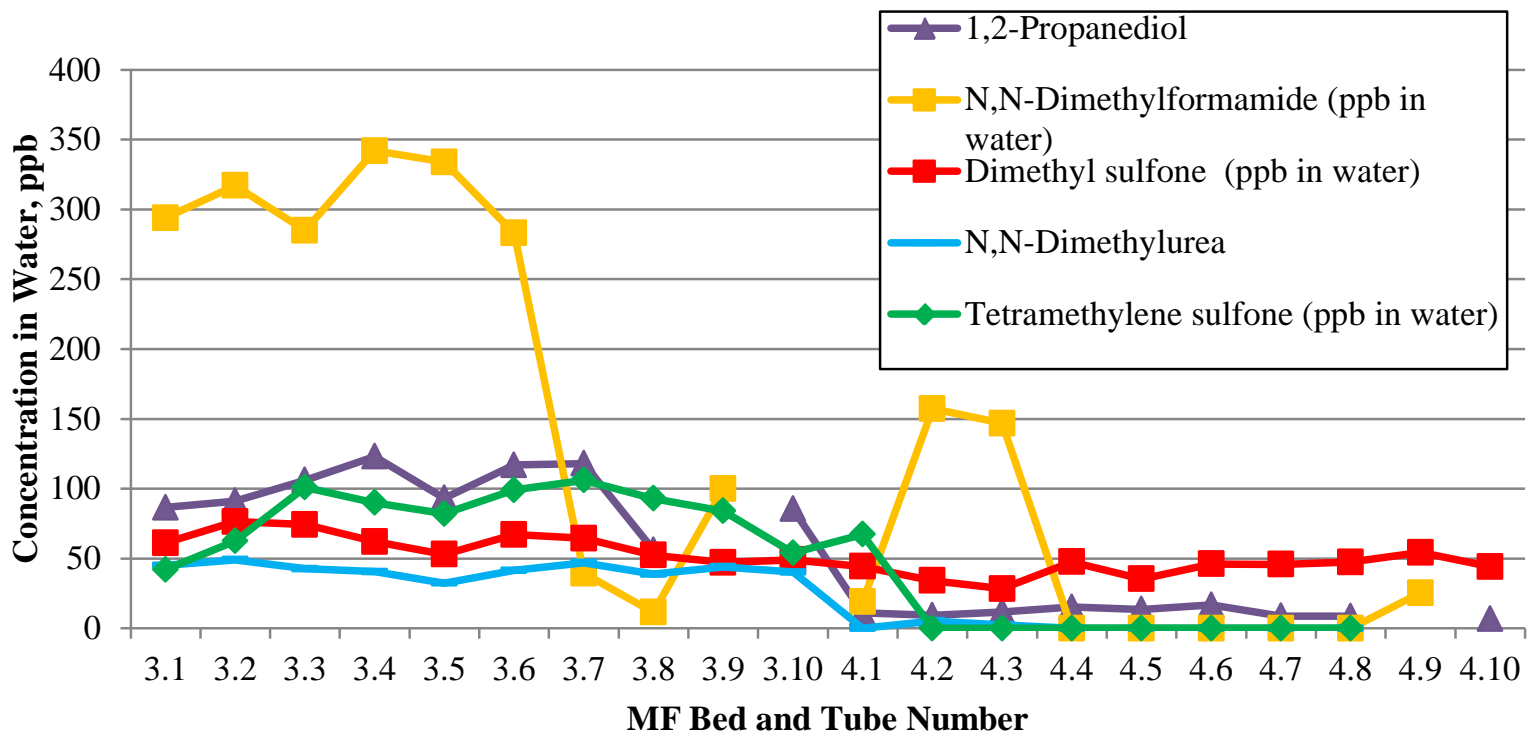

Figure 6. Concentration profile of selected semivolatile compound in water through MF Bed S/N 0003 and 0004.

American Institute of Aeronautics and Astronautics 
wastewater feed). The other compounds shown in Figure 6 appear in the water until they are completely removed by the sorbents as they travel through the MF Beds. Generally, the MF Beds function as designed and do an excellent job of removing organic compounds from the wastewater stream before it is sent on to the Catalytic Reactor.

\section{Analysis of Organics Desorbed from Selected Sorbents}

Adsorbent samples from tubes 1 through 3 and four ion exchange resin samples (tube 4 inlet and tube 10 inlet, middle, and outlet) were desorbed and the desorbates analyzed for semivolatile organic compounds and for volatile fatty acids (VFAs). Results are summarized here in units of mass per gram of dry sorbent.

VFA concentrations on MF Bed S/N 0004 sorbent samples ranged from non-detect up to about $0.2 \mathrm{mg} / \mathrm{g}$. In contrast, the lowest measured VFA sorbent loading in the MF Bed S/N 0003 samples was $0.92 \mathrm{mg} / \mathrm{g}$ on tube 10. This confirms that acetate ion was not yet breaking through the first bed $(\mathrm{S} / \mathrm{N} \mathrm{0003)}$ in any large amount. So the observed increase in conductivity measured with the in-line sensor in the WPA on ISS is confirmed to be due primarily to bicarbonate ion and not due to acetate ion.

A summary of adsorbent semivolatiles loadings for MF Bed S/N 0004 is shown in Figure 7, and the same information for MF Bed S/N 0003 is shown in Figure 8 for comparison. The loading on MF Bed S/N 0004 was much lower than in S/N 0003 . Tubes 1 through 3 for MF Bed S/N 0004 are 520 to 570 micrograms per gram, while the lowest adsorbent loading in MF Bed S/N 0003 was about 2000 micrograms per gram of adsorbent. The silane / siloxane compounds make up $25-45 \%$ of the total loadings on MF Bed S/N 0004 and include large siloxanes (hexamethylcyclotrisiloxane, octamethylcyclotetrasiloxane, decamethylcyclopentasiloxane, and other unidentified siloxanes) as well as some DMSD. The other primary compounds on these first three sorbents in S/N 0004 were 2ethoxyethanol and N,Ndimethylformamide. Another suspected, but unconfirmed, silicon containing compound was observed but is not included in the silane/siloxane total. The lowest siloxane loading is in tube 4.1 where other compounds compete for sorption sites. These data indicate that there was only minor breakthrough of organics from the first MF Bed to the second and that a large portion of the organics that did break through was siloxanes.

Figure 9 summarizes the semivolatile organic compound analysis results of the base desorption, base/neutral extract of the ion exchange resin samples for MF Beds S/N 0004. Similar data are shown in Figure 10 for $\mathrm{S} / \mathrm{N}$ 0003. As shown in Figure 9 for

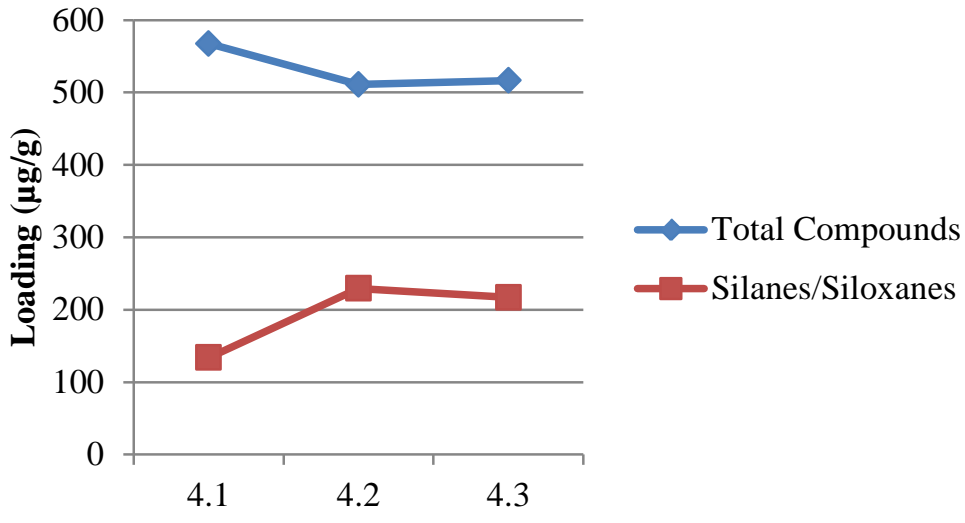

Figure 7. MF Bed S/N 0004 semivolatiles loading on adsorbent in tubes 1 through 3 . Note that the $y$-axis units are micrograms per gram of adsorbent.

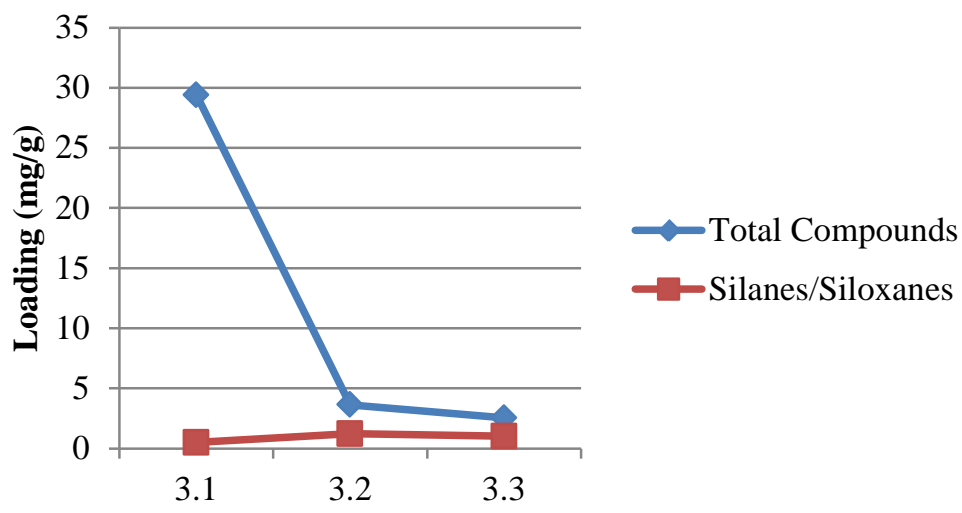

Figure 8. MF Bed S/N 0003 semivolatiles loading on adsorbent in tubes 1 through 3 . Note that the $y$-axis units are milligrams per gram of adsorbent.

American Institute of Aeronautics and Astronautics 
MF Bed S/N 0004, the total loading on the tube 4 inlet sample is very low, as expected, because the water has been well cleaned of organics by both the first MF Bed (S/N 0003) and tubes 4.1 through 4.3 of the second MF Bed. The amine loading on the tube 4.4 sample inlet resin from MF Bed S/N 0004 is about one third that on the tube 3.10 resin composite sample from MF Bed S/N 0003, indicating that only a small amount of the weak base anion exchange resin breakdown product from the first MF Bed reached the second MF Bed. The main amine observed on the tube 4.10 inlet sample is $\mathrm{N}, \mathrm{N}$-dimethyl-1,3-propanediamine, which was previously identified as a weak base anion exchange resin breakdown product. The presence of the breakdown product in tube 4.10 clearly shows that the weak base anion exchange resin in tube 4.9 is breaking down during use in the second MF Bed, as it was in the first. This also implies that the breakdown of the resin occurs regardless of the presence or absence of acetate ion. The loading on the tube 4.10 inlet sample from MF Bed S/N 0004 is about ten times that of the composite sample from tube 3.10 in MF Bed S/N 0003. It is reasonable that the inlet would be more highly loaded than a composite sample, so this is not completely unexpected. The only silane / siloxane compounds observed in tube 4.10 in MF Bed S/N 0004 were DMSD and a very small amount of a single large, unidentified siloxane on the inlet resin sample. The general lack of large siloxanes in tube 4.10, especially when compared to tubes 4.1 through 4.3, indicates that siloxanes, with the single exception of DMSD, did not break through the second MF Bed (S/N 0004). Table 2 summarizes the chemical species of interest and an indication of which beds showed breakthrough for these species.

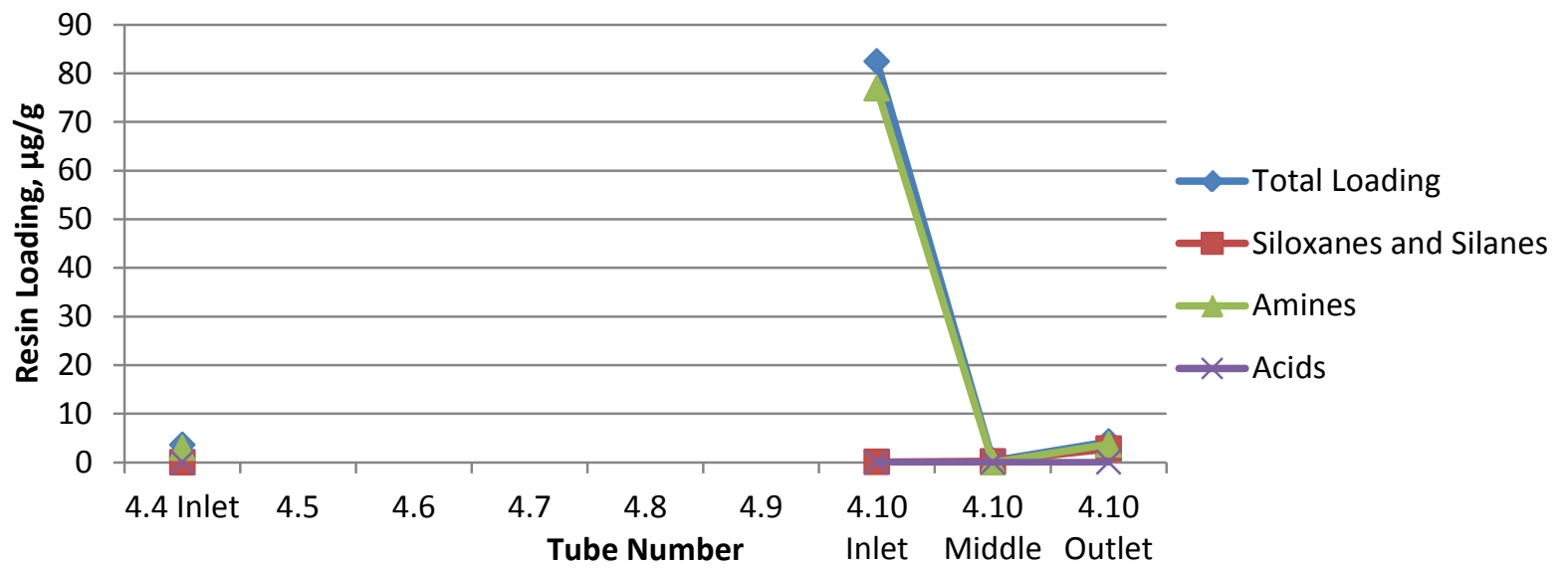

Figure 9. MF Bed S/N 0004 ion exchange resin base desorption, base/neutral extract semivolatile compounds summary.

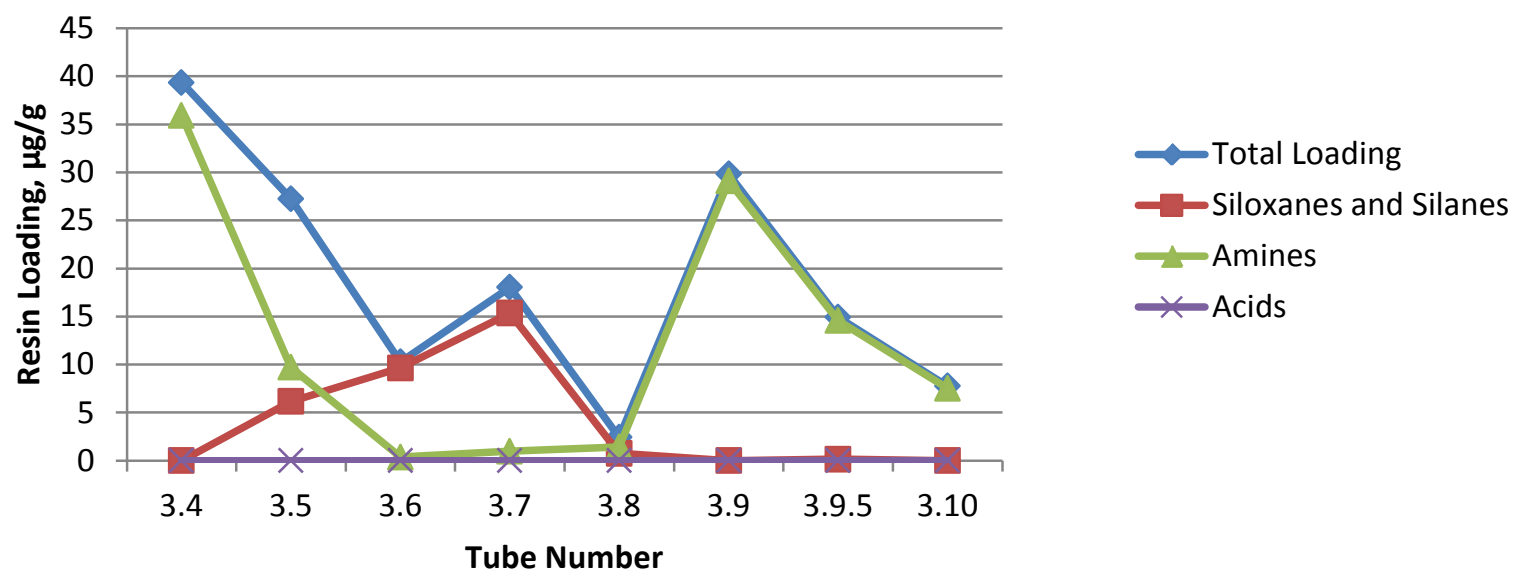

Figure 10. MF Bed S/N 0003 ion exchange resin base desorption, base/neutral extract semivolatile compounds summary. 
Table 2. Summary of breakthrough species for MF Beds S/N 0003 (first) and S/N 0004 (second) installed in the ISS WPA.

\begin{tabular}{|c|c|c|}
\hline Constituent & $\begin{array}{c}\text { MF Bed S/N 0003 } \\
\text { Breakthrough? }\end{array}$ & $\begin{array}{c}\text { MF Bed S/N 0004 } \\
\text { Breakthrough? }\end{array}$ \\
\hline Bicarbonate & Yes & No \\
\hline Inorganics & No & No \\
\hline Acetate & No & No \\
\hline Organics & Minor & No \\
\hline Dimethyl sulfone & Yes & Yes \\
\hline Siloxanes & Yes & No \\
\hline DMSD & Yes & Yes \\
\hline
\end{tabular}

\section{Microbiological Analysis}

Sampling for MF Bed S/N 0004 was more representative of the composite makeup of each tube for both water and sorbent as compared to the grab sampling approach used for MF Bed S/N 0003. Samples of both water and sorbent from each tube (including the two separate sorbents from tube 9) were analyzed for enumeration of heterotrophic bacteria and total fungi. Identification to species and relative abundance were performed for each specific colony morphology.

Figure 11 provides heterotrophic bacteria counts in water and sorbents from each tube in S/N 0003 and S/N 0004. Bacteria in water ranged from $<10 \mathrm{CFU} / 100 \mathrm{~mL}$ to $2.7 \mathrm{E}+04 \mathrm{CFU} / 100 \mathrm{~mL}$ for S/N 0003 and $<10 \mathrm{CFU} / 100$ $\mathrm{mL}$ to $4.9 \mathrm{E}+07 \mathrm{CFU} / 100 \mathrm{~mL}$ The slightly higher counts in $\mathrm{S} / \mathrm{N} 0004$ water may be due to several factors including different sampling protocols (grab samples in S/N 0003 versus composite samples in S/N 0004), longer storage time before sampling, and different chemical conditions (nutrients as well as possible inhibitors). Colonies cultured from water samples from tube 2, 8, and 9 were unusually small, translucent, and difficult to visualize without

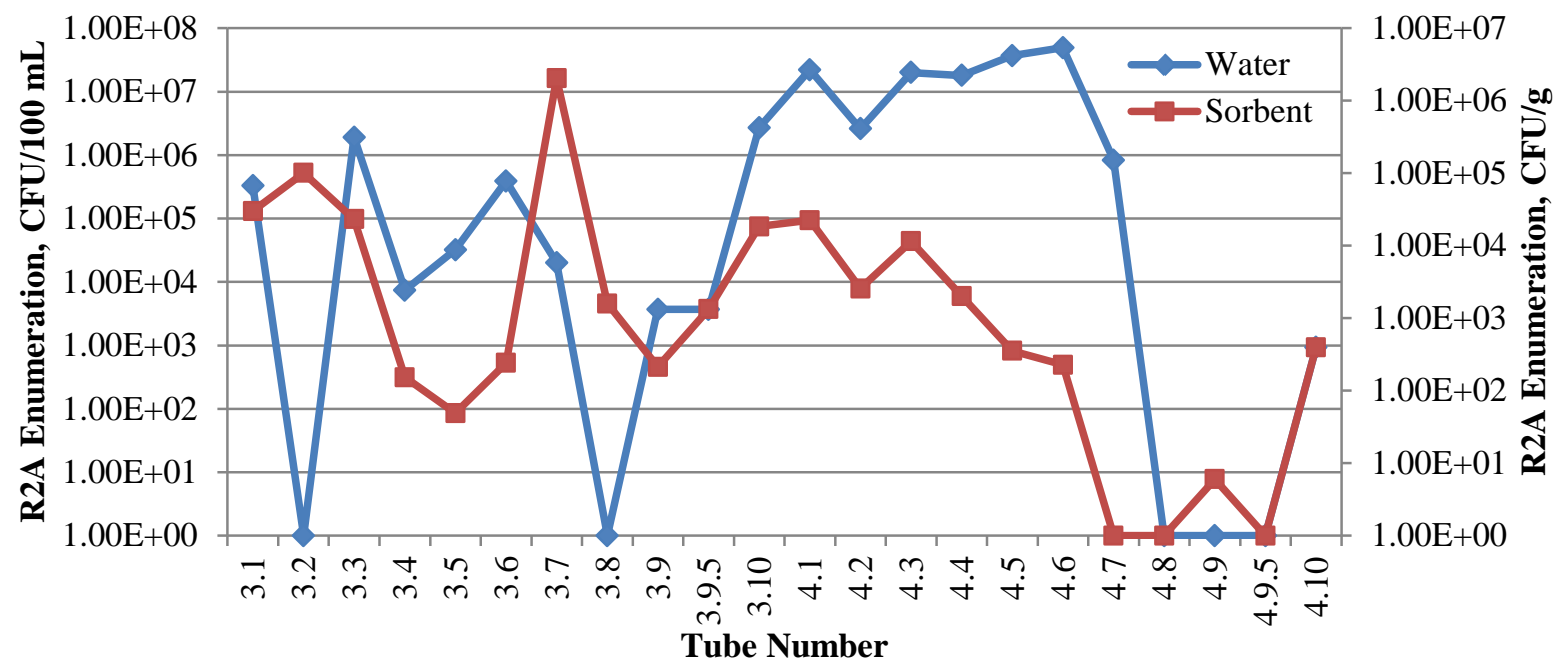

Figure 11. Heterotrophic bacterial enumeration (R2A) comparison between MF Bed S/N 0003 and 0004. 
magnification. Heterotrophic bacterial enumeration (R2A) results of the sorbent samples are similar between the two beds with the exception of tubes 7 and 8 . This difference may be due to different chemical conditions in the two beds. MF Bed S/N 0003 had both siloxanes and VFAs in tubes 7 and 8 while tubes 7 and 8 in MF Bed S/N 0004 were much cleaner. There were minimal fungi counts in three water samples (tubes 2, 3, and 8) each having 1-2 $\mathrm{CFU} / 100 \mathrm{~mL}$. All other samples were below detectible limits for fungi. The fungi identified were common airborne contaminants and are most likely due to contamination during collection of composite samples.

Predominant organisms identified in MF Bed S/N 0004 and S/N 0003 samples are shown in Figure 12 and in Figure 13, respectively. The predominant organisms throughout MF bed S/N 0003 are Burkholderia cepacia and Ralstonia pickettii, whereas the predominant organism throughout MF bed S/N 0004 was Ralstonia pickettii. Bradyrhizobium japonicum, Burkholderia cepacia, Ralstonia pickettii, an unidentified GNR similar to Phyllobacterium, and an unidentified GNR similar to Flavobacterium were isolated in both MF Beds. Achromobacter xylosoxidans, Stenotrophomonas maltophilia, Ochrobactrum anthropi, Janthinobacterium lividum, Methylobacterium species, and an unidentified GNR similar to Paracoccus were isolated only from S/N 0004. Burkholderia cenocepacia and Cupriavidus metallidurans were isolated only from $\mathrm{S} / \mathrm{N} 0003$. A graphical summary of predominant organisms identified in both MF Beds is shown in Figure 14. The bacteria present on the adsorbent, ion exchange resins, and in the water drained from the multifiltration beds are Gram negative species commonly found in wastewater, soil, and deionized water. 


\section{Bacteria in Water}

\section{MF Bed S/N 0004}

\begin{tabular}{|c|c|c|c|}
\hline Tube 1 - Ralstonia pickettii & \multicolumn{2}{|c|}{$\begin{array}{c}\text { Tube } 1-\text { Adsorbent } \\
\text { Water }-2.2 E+07 \text { CFU/100 mL; Resin - 2.24E+04 CFU/g }\end{array}$} & $\begin{array}{l}\text { Tube } 1 \text { - Burkholderia cepacia } \\
\text { Tube } 1 \text { - Unidentified GNR (low match } \\
\text { Phyllobacterium) }\end{array}$ \\
\hline \multirow{2}{*}{$\begin{array}{l}\text { Tube } 2 \text { - Unidentified GNR (low match } \\
\text { Phyllobacterium) } \\
\text { Tube } 2 \text { - Ralstonia pickettii }\end{array}$} & \multirow{2}{*}{\multicolumn{2}{|c|}{$\begin{array}{c}\text { Tube } 2 \text { - Adsorbent } \\
\text { Water 2.6E+06 CFU/100 mL; Resin - 2.56E+03 CFU/g }\end{array}$}} & Tube 1 - Methylobacterium species \\
\hline & & & $\begin{array}{l}\text { Tube } 2 \text { - Ralstonia pickettii } \\
\text { Tube } 2 \text { - Ochrobactrum anthropi }\end{array}$ \\
\hline $\begin{array}{l}\text { Tube } 3 \text { - Ralstonia pickettii } \\
\text { Tube } 3 \text { - Ochrobactrum anthropi }\end{array}$ & \multicolumn{2}{|c|}{$\begin{array}{c}\text { Tube } 3-\text { Adsorbent } \\
\text { Water }-2.0 \mathrm{E}+07 \mathrm{CFU} / 100 \mathrm{~mL} ; \text { Resin }-1.15 \mathrm{E}+04 \mathrm{CFU} / \mathrm{g}\end{array}$} & $\begin{array}{l}\text { Tube } 3 \text { - Ochrobactrum anthropi } \\
\text { Tube } 3 \text { - Ralstonia pickettii }\end{array}$ \\
\hline Tube 4 - Burkholderia cepacia & \multicolumn{2}{|c|}{$\begin{array}{l}\text { Tube } 4 \text { - Mixed Ion Exchange Resin } \\
\text { Water - 7.4E+03 CFU/100 mL; Resin - 2.02E+03 CFU/g }\end{array}$} & $\begin{array}{l}\text { Tube } 4 \text { - Ochrobactrum anthropi } \\
\text { Tube } 4 \text { - Bradyrhizobium japonicum } \\
\text { Tube } 4 \text { - Unidentified GNR (low match } \\
\text { Paracoccus) }\end{array}$ \\
\hline \multirow{2}{*}{$\begin{array}{l}\text { Tube } 5 \text { - Ralstonia pickettii } \\
\text { Tube } 5 \text { - Unidentified GNR (low match } \\
\text { Flavobacterium) }\end{array}$} & & & Tube 4 - Janthinobacterium lividum \\
\hline & \multicolumn{2}{|c|}{$\begin{array}{l}\text { Tube } 5 \text { - Mixed Ion Exchange Resin } \\
\text { Water - 3.7E+07 CFU/100 mL; Resin - 3.54E+02 CFU/g }\end{array}$} & Tube 5 - Bradyrhizobium japonicu \\
\hline Tube 6 - Ralstonia pickettii & \multicolumn{2}{|c|}{$\begin{array}{c}\text { Tube } 6 \text { - Mixed Ion Exchange Resin } \\
\text { Water }-4.9 E+07 \text { CFU/100 mL; Resin - 2.27E+02 CFU/g }\end{array}$} & $\begin{array}{l}\text { Tube } 6 \text { - Unidentified GNR (low match } \\
\text { Paracoccus) } \\
\text { Tube } 6 \text { - Unidentified GNR (low match }\end{array}$ \\
\hline Tube 7 - Ralstonia pickettii & \multicolumn{2}{|c|}{$\begin{array}{l}\text { Tube } 7 \text { - Mixed lon Exchange Resin } \\
\text { Water - 8.3E+05 CFU/100 mL; Resin - <2 CFU/g }\end{array}$} & Tube 7 - No Bacteria Detected \\
\hline Tube 8 - No Bacteria Detected & \multicolumn{2}{|c|}{$\begin{array}{l}\text { Tube } 8 \text { - Mixed Ion Exchange Resin } \\
\text { Water - <1 CFU/100mL; Resin - <2 CFU/g }\end{array}$} & Tube 8 - No Bacteria Detected \\
\hline Tube 9 Water - <1 CFU/100mL & $\begin{array}{l}\text { Tube } 9 \text { Weak-Base Anion } \\
\text { Exchange Resin } \\
\text { Resin }-<2 \text { CFU/g }\end{array}$ & $\begin{array}{l}\text { Tube 9- Strong-Acid Cation } \\
\text { Exchange Resin } \\
\text { Resin - } 6 \text { CFU/g }\end{array}$ & $\begin{array}{l}\text { Tube } 9 \text { (Cat) - Stenotrophomonas maltophilia } \\
\text { Tube } 9 \text { (Cat) - Achromobacter xylosoxidans }\end{array}$ \\
\hline Tube 10 - Ralstonia pickettii & \multicolumn{2}{|c|}{$\begin{array}{c}\text { Tube } 10 \text { - Mixed lon Exchange Resin } \\
\text { Water } 9.3 E+02 \text { CFU/100 mL; Resin 3.97E+02 CFU/g }\end{array}$} & Tube 10 - Bradyrhizobium japonicum \\
\hline
\end{tabular}

Figure 12. Summary of bacteria isolated and identified in water and sorbent samples from MF Bed S/N 0004 .

12

American Institute of Aeronautics and Astronautics

\section{Bacteria on Resins} Phyllobacterium) Tube 1 - Ralstonia pickettii

lobacterium species

Tube 3 - Ochrobact

Tube 4 -Ochrobactrum anthropi

Tube 4 - Bradyrhizobium japonicum

Tube 4 - Unidentified GNR (low match Paracoccus)

Tube 6 - Unidentified GNR (low match

Tube 6 - Unidentified GNR (low match

\section{.}

(1) 


\begin{tabular}{|c|c|c|c|}
\hline Bacteria in Water & \multicolumn{2}{|c|}{ MF Bed S/N 0003} & Bacteria on Resins \\
\hline $\begin{array}{l}\text { Tube } 1 \text { - Bradyrhizobium japonicum } \\
\text { Tube } 1 \text { - Unidentified GNR (low match } \\
\text { Phyllobacterium) }\end{array}$ & \multicolumn{2}{|c|}{$\begin{array}{c}\text { Tube } 1-\text { Adsorbent } \\
\text { Water }-3.3 \mathrm{E}+05 \mathrm{CFU} / 100 \mathrm{~mL} \text {; Resin }-3.00 \mathrm{E}+04 \mathrm{CFU} / \mathrm{g}\end{array}$} & $\begin{array}{l}\text { Tube } 1 \text { - Ralstonia pickettii } \\
\text { Tube } 1 \text { - Cupriavidus metallidurans }\end{array}$ \\
\hline Tube 2 - No Bacteria Detected & \multicolumn{2}{|c|}{$\begin{array}{c}\text { Tube } 2 \text { - Adsorbent } \\
\text { Water <10 CFU/100 mL; Resin - 1.01E+05 CFU/g }\end{array}$} & $\begin{array}{l}\text { Tube } 2 \text { - Unidentified GNR (low match } \\
\text { Phyllobacterium) } \\
\text { Tube } 2 \text { - Cupriavidus metallidurans }\end{array}$ \\
\hline $\begin{array}{l}\text { Tube } 3 \text { - Bradyrhizobium japonicum } \\
\text { Tube } 3 \text { - Unidentified GNR (low match } \\
\text { Phyllobacterium) }\end{array}$ & \multicolumn{2}{|c|}{$\begin{array}{c}\text { Tube } 3-\text { Adsorbent } \\
\text { Water }-1.9 \mathrm{E}+06 \mathrm{CFU} / 100 \mathrm{~mL} \text {; Resin }-2.00 \mathrm{E}+04 \mathrm{CFU} / \mathrm{g}\end{array}$} & $\begin{array}{l}\text { Tube } 3 \text { - Unidentified GNR (low match } \\
\text { hyllobacterium) } \\
\text { Tube } 3 \text { - Bradyrhizobium japonicum }\end{array}$ \\
\hline $\begin{array}{l}\text { Tube } 4 \text { - Bradyrhizobium japonicum } \\
\text { Tube } 4 \text { - Ralstonia pickettii } \\
\text { Tube } 4 \text { - Burkholderia cepacia }\end{array}$ & \multicolumn{2}{|c|}{$\begin{array}{l}\text { Tube } 4 \text { - Mixed Ion Exchange Resin } \\
\text { Water - 7.4E+03 CFU/100 mL; Resin - 1.53E+02 CFU/g }\end{array}$} & Tube 4 - Ralstonia pickettii \\
\hline $\begin{array}{l}\text { Tube } 5 \text { - Ralstonia pickettii } \\
\text { Tube } 5 \text { - Cupriavidus metallidurans } \\
\text { Tube } 5 \text { - Unidentified GNR (low match } \\
\text { Flavobacterium) }\end{array}$ & \multicolumn{2}{|c|}{$\begin{array}{l}\text { Tube } 5 \text { - Mixed Ion Exchange Resin } \\
\text { Water - 3.2E+04 CFU/100 mL; Resin - } 49 \text { CFU/g }\end{array}$} & $\begin{array}{l}\text { Tube } 5 \text { - Ralstonia pickettii } \\
\text { Tube } 5 \text { - Unidentified GNR (low match } \\
\text { Flavobacterium) } \\
\text { Tube } 5 \text { - Burkholderia cenocepacia }\end{array}$ \\
\hline $\begin{array}{l}\text { Tube } 6 \text { - Ralstonia pickettii } \\
\text { Tube } 6 \text { - Burkholderia cepacia } \\
\text { Tube } 6 \text { - Unidentified GNR (low match } \\
\text { Flavobacterium) }\end{array}$ & \multicolumn{2}{|c|}{$\begin{array}{c}\text { Tube } 6 \text { - Mixed Ion Exchange Resin } \\
\text { Water - 3.9E+05 CFU/100 mL; Resin - 2.42E+02 CFU/g }\end{array}$} & $\begin{array}{l}\text { Tube } 6 \text { - Ralstonia pickettii } \\
\text { Tube } 6 \text { - Unidentified GNR (low match } \\
\text { Flavobacterium) }\end{array}$ \\
\hline $\begin{array}{l}\text { Tube } 7 \text { - Burkholderia cepacia } \\
\text { Tube } 7 \text { - Burkholderia cenocepacia }\end{array}$ & \multicolumn{2}{|c|}{$\begin{array}{c}\text { Tube } 7 \text { - Mixed Ion Exchange Resin } \\
\text { Water - 2.0E+04 CFU/100 mL; Resin -2.03E+06 CFU/g }\end{array}$} & $\begin{array}{l}\text { Tube } 7 \text { - Burkholderia cepacia } \\
\text { Tube } 7 \text { - Burkholderia cenocepacia }\end{array}$ \\
\hline \multirow{2}{*}{$\begin{array}{l}\text { Tube } 8 \text { - No Bacteria Detected } \\
\qquad \text { Tube } 9 \text { Water }-3.7+0 \mathrm{E} 3 \mathrm{CFU} / 100 \mathrm{~mL}\end{array}$} & \multirow{2}{*}{\multicolumn{2}{|c|}{$\begin{array}{c}\text { Tube } 8 \text { - Mixed Ion Exchange Resin } \\
\text { Water - <10 CFU/100mL; Resin - 1.84E+03 CFU/g }\end{array}$}} & $\begin{array}{l}\text { Tube } 8 \text { - Burkholderia cepacia } \\
\text { Tube } 8 \text { - Ralstonia pickettii }\end{array}$ \\
\hline & & & \\
\hline $\begin{array}{l}\text { Tube } 9 \text { - Ralstonia pickettii } \\
\text { Tube } 9 \text { - Burkholderia cepacia } \\
\text { Tube } 9 \text { - Unidentified GNR (low match } \\
\text { Flavobacterium) }\end{array}$ & $\begin{array}{l}\text { Tube } 9 \text { Weak-Base Anion } \\
\text { Exchange Resin } \\
\text { Resin - } 1.33 E+03 \text { CFU/g }\end{array}$ & $\begin{array}{l}\text { Tube } 9 \text { - Strong-Acid } \\
\text { Cation Exchange Resin } \\
\text { Resin - 2.13E+02 CFU/g }\end{array}$ & $\begin{array}{l}\text { Tube } 9 \text { (weak and strong base resins) - } \\
\text { Burkholderia cepacia } \\
\text { Tube } 9 \text { (weak and strong base resins) - } \\
\text { Burkholderia cenocepacia }\end{array}$ \\
\hline $\begin{array}{l}\text { Tube } 10 \text { - Ralstonia pickettii } \\
\text { Tube } 10 \text { - Burkholderia cepacia } \\
\text { Tube } 10 \text { - Burkholderia cenocepacia }\end{array}$ & \multicolumn{2}{|c|}{$\begin{array}{l}\text { Tube } 10 \text { - Mixed Ion Exchange Resin } \\
\text { Water 2.7E+06 CFU/100 mL; Resin 1.84E+04 CFU/g }\end{array}$} & $\begin{array}{l}\text { Tube } 10 \text { - Burkholderia cepacia } \\
\text { Tube } 10 \text { - Burkholderia cenocepacia }\end{array}$ \\
\hline
\end{tabular}

Figure 13. Summary of bacteria isolated and identified in water and sorbent samples from MF Bed S/N 0003, provided for comparison purposes.

13

American Institute of Aeronautics and Astronautics 


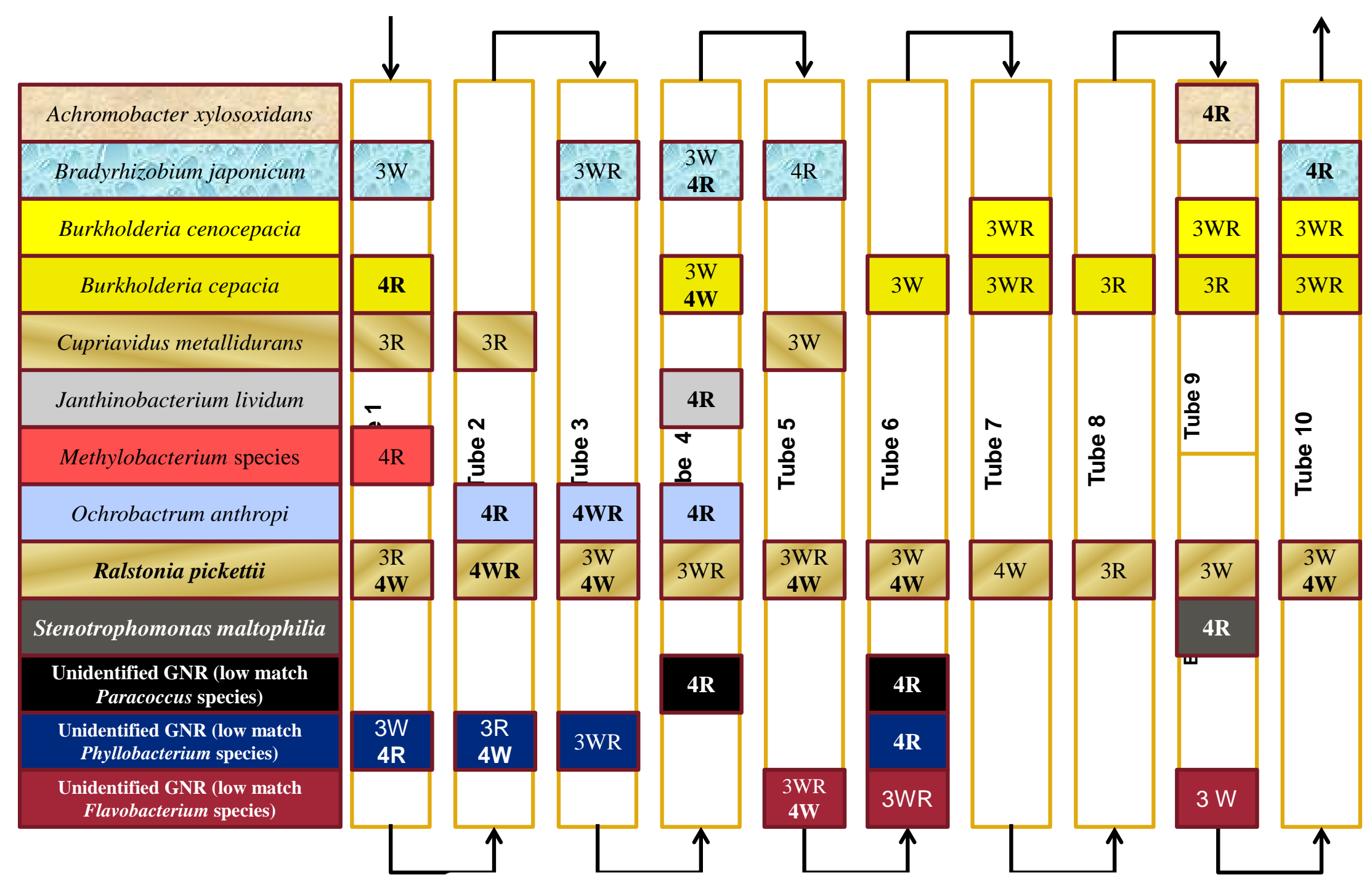

3 - S/N 0003, 4 - S/N 0004, W - Water, R - Resin

Figure 14. Comparison of bacteria isolated and identified in MF Bed S/N 0003 and S/N 0004 samples. 


\section{Conclusions}

In summary, microbiological analysis showed that the predominant organisms in MF Bed S/N 0004 are very similar to those in $\mathrm{S} / \mathrm{N} 0003$. Organisms that were identified in one bed but not the other have all been previously identified in ISS samples. The enumeration profiles through the two beds are different, which is expected because the chemical profile through the two beds is different (variations in nutrients, potential inhibitors, and $\mathrm{pH}$, for example). Additionally, a comparison between microbial analysis results of the two beds confirms that the predominant organisms are similar despite the different storage times, histories, and sampling protocols. Based on the enumeration results, nutrients appear to be gone by tubes 7 and 8 in MF Bed S/N 0004.

The chemical analysis of the MF Bed S/N 0004 samples has served to answer several targeted questions. First, analysis confirms that DMSD is not well retained by either the adsorbents or the ion exchange resins in the MF Beds and is, in fact, breaking through both the first and second beds installed in series in the WPA. Given the fact that the DMSD is ultimately present in the product water (ref DMSD ICES 2013), this result indicates a need to modify either the MF Beds or the Cat Reactor to increase capacity for DMSD or to develop a process that prevents DMSD from entering the ISS condensate. Second, analysis shows that although polysiloxanes appear to be better retained than DMSD, they are best retained on the adsorbent in tubes 1 through 3 where there is little competition from other compounds. In both MF Beds S/N 0003 and S/N 0004, there is a peak in silane / siloxane compounds mid-bed. This may be caused by competition for ion exchange sorption sites that causes the silanes and siloxanes, which are more poorly retained than many other compounds, to move further through the bed. If the MF Beds were used to their full capacity to remove ionic and organic compounds (other than organosilicon compounds like DMSD and siloxanes), it is possible that the organosilicon compounds would be pushed downstream through the bed, eventually appearing in the MF Bed effluent and possibly impacting the performance of the Catalytic Reactor. Furthermore, the MF Bed must be modified to include media specific for removal of the polysiloxanes such that the first bed has enough capacity to retain the polysiloxanes until ionic breakthrough. Otherwise, eventually the polysiloxanes will saturate both MF Beds and most likely impact reactor performance due to their large molecular weight. Third, it is unlikely that large silane / siloxane compounds are passing through both MF Beds to reach the catalytic reactor based on this data. This means that siloxanes were not impacting reactor performance which would have prevented the Catalytic Reactor from fully oxidizing DMSD. This observation has been confirmed with reactor tests that have shown that the reactor has insufficient capacity for the DMSD concentration in the MF Bed effluent (ref DMSD 2013 ices papers) that has been observed once DMSD saturates the MF Bed. Fourth, analysis of the second bed confirms that dimethyl sulfone is present throughout both beds in the water samples and many of the sorbent samples. Dimethyl sulfone was likely present in the MF Bed S/N 0004 effluent and was sent to the catalytic reactor at a concentration of about $50 \mathrm{ppm}$. In fact, dimethyl sulfone has been measured in product water samples returned to ground for analysis. Although the presence of dimethyl sulfone in product water at these levels is acceptable for most uses, any changes to the MF Bed for other reasons should also be evaluated for their ability to improve removal of dimethyl sulfone. Fifth, breakdown products or leachates of the weak base anion exchange resin used in tube 9 appear to be mostly adsorbed by the ion exchange resin in tube 10 for each MF Bed. Although the weak-base anion exchange resin breakdown occurs during both use and storage, the MF Beds are successfully removing the breakdown product.

\section{Acknowledgments}

The authors would like to thank Eric Cramblit, Lauren Holden, and Samuel Manuel of Boeing; Harold Cole (retired); Barbara Peyton and Warren Edwards of Hamilton Sundstrand Space Systems International (HSSSI), A UTC Aerospace Systems Company; and Douglas Snowdon (retired). 


\section{References}

1. Status of the Regenerative ECLSS Water Recover System. Carter, D. L. and Orozco, N. Portland, Oregon : AIAA 1021863, July 2011. presented at the 41st International Conference on Environmental Systems.

2. Performance Evaluation of the ISS Water Processor Multifiltration Beds. Bowman, E. M, Carter, D. L., Wilson, M., Cole, H., Orozco, N., Snowdon, D. San Diego, CA : AIAA 2012-3596, July 15-19, 2012. presented at the 42nd International Conference on Environmental Systems.

3. Intramolecular General Base Catalysis in the Aminolysis of Acetylimidazole and Methyl Formate by Diamines.

Page, M. I, and Jencks, W. P. 25, 1972, J. Am. Chem. Soc., Vol. 94, pp. 8818-8827. 